\title{
Tabuleiro de Genes: uma ferRamenta Pedagógica PARA O ENSINO DE BIOLOGIA
}

\author{
GENE OF GAME BOARD: AN EDUCATIONAL TOOL FOR TEACHING BIOLOGY
}

DOI: 10.23926/RPD.2526-2149.2020.v5.n2.p1093-1110.id738

\section{Thays Cristina Ribeiro \\ Alves \\ Licenciada em Ciências \\ Naturais/Biologia (UFMA) \\ thayscris21@gmail.com}

\section{Marcones Ferreira}

\section{Costa}

Mestre em Genética e

Melhoramento (UFPI)

Professor na Universidade

Federal do Piauí (UFPI)

marconescosta@ufpi.edu.br

\section{Camila Campêlo de}

\section{Sousa}

Doutora em Genética e

Melhoramento

(ESALQ/USP)

Professora na Universidade

Federal do Maranhão

(UFMA)

camila.campelo@ufma.br
Resumo: Estudantes da educação básica apresentam dificuldades na assimilação dos conceitos de Genética; desse modo, o objetivo deste trabalho é apresentar o jogo "Tabuleiro de Genes" como ferramenta para o ensino de Genética. O jogo é constituído por um tabuleiro com 24 cartas contendo perguntas e respostas, confeccionado a partir de materiais alternativos e de fácil reprodutibilidade. Foi utilizado como procedimento metodológico a observação direta com a utilização de questionário de avaliação. O instrumento pedagógico foi aplicado em novembro de 2015. Participaram 23 discentes do $3^{\circ}$ ano do Ensino Médio de uma escola pública, no município de Codó (MA). Ao aplicar o jogo, percebeu-se a importância em aliar a teoria com a prática. Também foi possível detectar a interação dos alunos, discutindo suas dúvidas e expressando ideias. Assim, o jogo atuou como um estimulador das atividades cognitivas, além de ampliar o contato de discentes com a Genética.

Palavras-chave: Aprendizagem. Educação; Genética. Material Didático.

\begin{abstract}
Basic education students have difficulties in assimilating the basic concepts of Genetics. The objective this work is to present the game "Tabuleiro de Genes" as a tool for teaching Genetics. The game consists of a board with 24 cards containing questions and answers, made from alternative materials and easily reproducible. It was used as a methodological procedure to direct observation using a questionnaire. The pedagogical instrument was applied in November 2015. The study involved 23 students of the third grade of High School of a public school, in the city of Codó (MA). When applying the game, one can see the importance of combining theory with practice. It was also possible to detect the interaction of students, discussing their questions and expressing ideas. Thus, the game served as a stimulator of cognitive activities, as well as to increase the contact of students with genetics.
\end{abstract}

Keywords: Learning. Education. Genetics. Courseware. 


\section{INTRODUÇÃO}

O processo de aprendizado dos conteúdos de Genética é considerado um dos mais desafiadores para alunos de Biologia do Ensino Médio, principalmente pela terminologia específica, conteúdo matemático e à natureza complexa associada aos diferentes níveis de organização biológica (VENTURINI et al., 2018).

Castelão e Amabis (2008) apontam que a motivação do aluno para aprender os conteúdos de Genética decorre de causas internas e externas, em especial, a figura do docente. Kishimoto (2017) ressalta que o professor deve adotar práticas que despertem o interesse do aluno. Diante deste contexto, o ensino de Genética exige métodos inovadores que associem a teoria com modelos práticos lúdicos e/ou jogos didáticos.

As práticas pedagógicas adotadas no ensino de Genética constituem-se basicamente de teoria com pouca contextualização (REZENDE; GOMES, 2018). Por conta disso, muito se discute sobre as dificuldades que os alunos do Ensino Médio sentem em determinados conteúdos da Genética (MASCARENHAS et al., 2016). Assim, para que o aluno tenha um entendimento amplo sobre esses assuntos, é necessário que ele saiba relacionar os processos biológicos ligados a hereditariedade com seu cotidiano (SANTOS et al., 2018). Neste sentido, os jogos didáticos configuram-se como importantes ferramentas para serem aplicadas no ensino de Genética, caracterizando-se como alternativa viável na construção do conhecimento e permitindo uma maior interação entre professor e aluno.

Segundo Melo et al. (2009), os jogos didáticos só serão ferramentas ideais para aprendizagem, se promoverem o interesse do aluno e auxiliarem na construção de novos saberes, atuando como facilitadores de aprendizagem. Há diversos estudos que ratificam a contribuição significativa dos jogos no processo de ensino-aprendizagem dos conteúdos de Biologia (SOARES et al., 2016; ACRANI et al., 2020), entretanto os mesmos ainda são pouco utilizados, principalmente os relacionados aos conteúdos de Genética.

Reconhecendo a importância da ludicidade para a construção do conhecimento, foi elaborado um jogo de tabuleiro, que visa facilitar a compreensão dos conteúdos de Genética no Ensino Médio. Nesse sentido, o presente trabalho tem como objetivo apresentar o jogo “Tabuleiro de Genes" como uma proposta didática que auxilie os alunos a obterem uma melhor compreensão e fixação dos conceitos relacionados à hereditariedade e à composição do material genético. O jogo apresenta como vantagens o baixo custo, a fácil preparação e utiliza regras básicas dos jogos de tabuleiros, as quais são conhecidas pela maioria dos alunos. Além disso, 
os discentes também podem participar da produção do material, atuando assim de forma ativa, desde a confecção até aplicação do recurso didático.

\section{REFERENCIAL TEÓRICO}

O Ensino de Biologia é uma verdadeira fonte de pesquisa e muitos educadores têm se preocupado com a forma que esse conhecimento científico tem sido transmitido para jovens e adolescentes. Por décadas, esse conhecimento era de caráter mais informativo, e com o passar do tempo, tornou-se necessário incorporar os objetivos de aprendizagem, criar relações entre áreas de conhecimento e dinamizar o ensino para além do livro didático (MELO et al., 2009).

A Genética tem ocupado uma posição central em toda a área biológica, no contexto de vários aspectos de interesse humano e tem conquistado grande reconhecimento pela sociedade, desde a área médica ao melhoramento de animais e plantas (GRIFFITHS et al., 2016). No entanto, há dificuldades de compreensão acerca dos conceitos que a fundamentam, por grande parte dos alunos do Ensino Médio. Estas dificuldades são oriundas de um ensino cujo modelo reducionista e sem contextualização, leva a concepções simplificadas que não consideram a relação dialética entre as partes (OLIVEIRA et al., 2016).

Ademais, o ensino de Genética permite várias relações interdisciplinares que devem ser trabalhadas de maneira significativa pelos docentes, uma vez que esta área de conhecimento está ligada às outras áreas da Biologia, sendo necessário que os alunos compreendam as estruturas celulares, suas organelas, suas moléculas e consigam correlacionar as suas funções com os mecanismos de hereditariedade (REZENDE; GOMES, 2018).

Segundo Krasilchik (2008), ao final do Ensino Médio, o indivíduo deve estar apto a utilizar o que aprendeu e ser capaz de tomar decisões de caráter individual e coletivo com responsabilidade e respeito ao meio em que vive.

A obtenção de resultados significativos no processo de ensino-aprendizagem é um grande desafio e requer habilidades e prática docente para chamar a atenção do estudante, principalmente dos alunos do Ensino Médio (CABRERA, 2007). No intuito de melhorar resultados negativos na área de ensino de Biologia, os professores têm se desdobrado em buscar práticas educativas para alcançar um aprendizado significativo e despertar o interesse dos educandos com estratégias de ensino diversificadas (PEDROSO, 2009).

Nessa perspectiva, o professor tem um importante papel mediador no processo científico, não basta dizer apenas como o processo ocorre, mas deve-se criar uma versatilidade de estratégias para que o aluno participe e descubra como ocorrem os mecanismos genéticos. 
Tais práticas, como por exemplo, revisão de conteúdos por meio de jogos didáticos, podem ajudar na dinâmica de aprendizagem e garantir que os objetivos sejam alcançados em uma maior magnitude (SILVA, 2019).

O jogo auxilia na construção de representações mentais com a manipulação de objetos e também fortalece as relações sociais dentro do ambiente de sala de aula. Esses benefícios não se restringem apenas ao aluno, mas também ao professor, que tem alunos mais participativos e criativos em sua aula.

Diante das dificuldades encontradas ao ensinar Genética para adolescentes, consolidar um conhecimento visto superficialmente por eles do ponto de vista do senso comum, para aprofundar cientificamente e torná-los capazes de argumentar com senso crítico, exige o planejamento de práticas bem elaboradas por parte do docente.

O professor que se sente desmotivado deve procurar meios para superar estas dificuldades, pois é fundamental assegurar o conhecimento de maneira clara sem fragmentá-lo, inserir exercícios e reflexões para que o aluno tenha consciência do todo, não trabalhando com uma abordagem que se limita a apresentação de termos científicos (BRÃO; PEREIRA, 2015). Nesse sentindo, os jogos pedagógicos ajudam a reverter essa situação, por deixarem as aulas mais atraentes conquistando o interesse dos alunos. Essas práticas lúdicas ainda fortalecem a relação entre professor e aluno (ARAÚJO, 2012; MARTINS et al., 2015).

Ressalta-se que os jogos não devem ser o principal meio de aprendizagem para o aluno, mas funcionam como apoio para reforçar certo objetivo de aprendizagem (AMORIM et al., 2016). Esse suporte de ensino deve ser instrutivo, transformando-se em uma competição divertida, e, que consiga de forma sutil, desenvolver um caminho correto ao aluno (FIALHO, 2008). Para Araújo (2012), o que faz o aluno aprender é a discussão, participação, construção, reconstrução, erro, correção, criação, investigação e autonomia. Nessa dinâmica, o aluno descobre que é capaz de aprender além do seu ambiente escolar, onde ele se torna pesquisador de seu próprio conhecimento.

\section{Metodologia}

Esta pesquisa utilizou a combinação de metodologias quantitativas e qualitativas para validação do jogo didático proposto. $\mathrm{O}$ estudo apoiou-se na observação direta, visando identificar os comportamentos e acontecimentos decorridos ao longo do processo de aplicação do jogo. 
O jogo "Tabuleiro de Genes" foi desenvolvido e confeccionado a partir de pesquisas em livros didáticos e nas bases de periódicos do Portal de Periódicos da Capes. Para a confecção do tabuleiro, utilizou-se os seguintes materiais: a) Papelão; b) E.V.A (etil vinil acetato) nas cores: vermelho nas bordas, representando os nucleosídeos e verde, laranja, amarelo e marrom representando as bases nitrogenadas; c) tesoura; d) cola; e) T. N. T (tecido não tecido) azul, para cobrir o papelão e f) impressões.

Foi criado e dado forma ao desenho gráfico do tabuleiro (Figura 1) no modelo duplahélice do DNA (ácido desoxirribonucleico), contendo as bases nitrogenadas em cores fantasias, além disso, foi feita a legenda para melhor compreensão do tabuleiro.

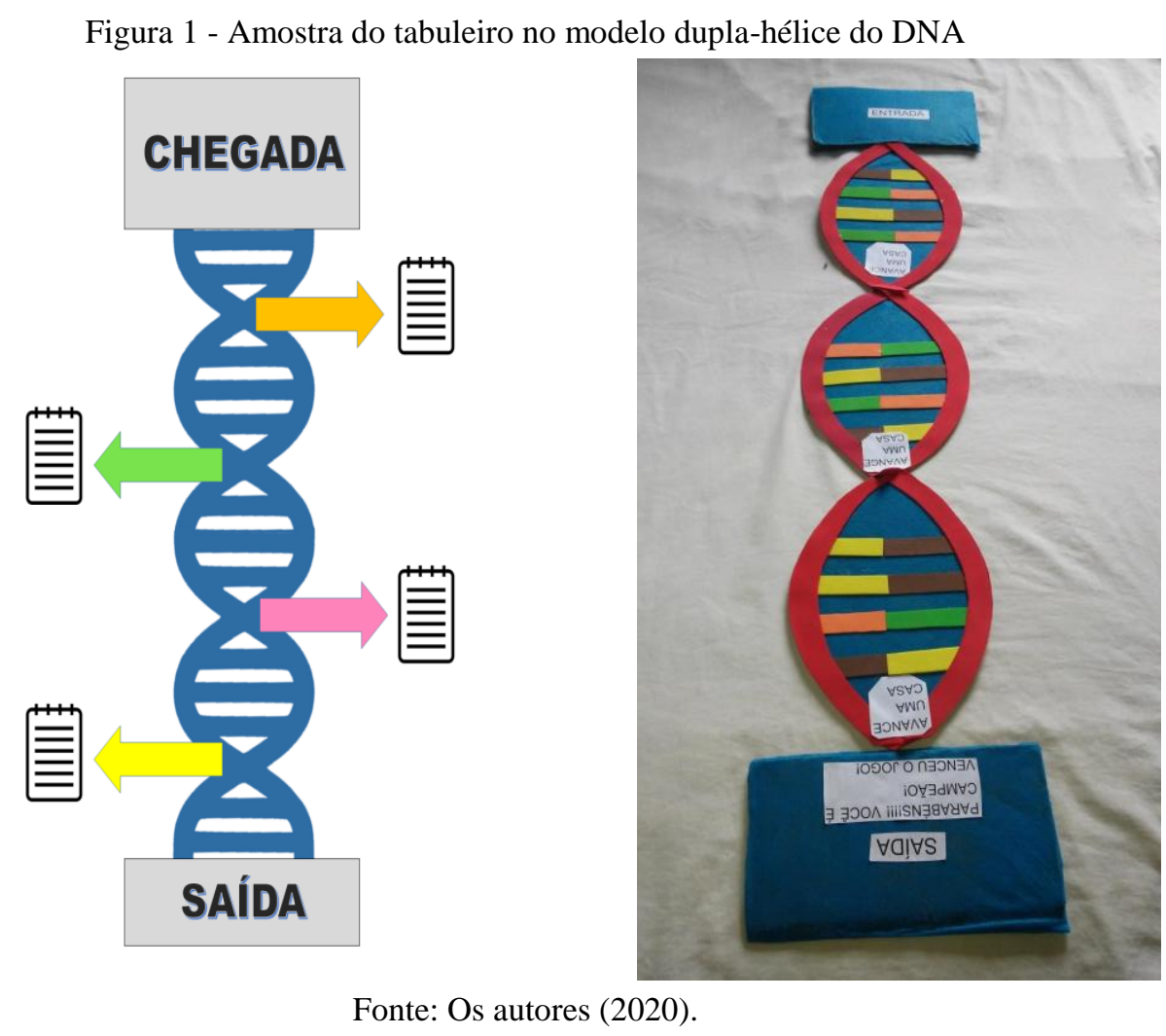

A partir dos conteúdos de Genética abordados nos livros didáticos do Ensino Médio, foram confeccionadas 24 cartas (Figura 2) contendo as perguntas e respostas (Anexo 1), que compõem o jogo de tabuleiro. Também foram criadas as regras do jogo (Anexo 2) e a lista de penalidades (Anexo 3). As cartas e a lista de penalidades devem ficar na mão do aplicador durante a aplicação do jogo.

Figura 2- 
Figura 2 - Modelos das cartas com perguntas e respostas do jogo
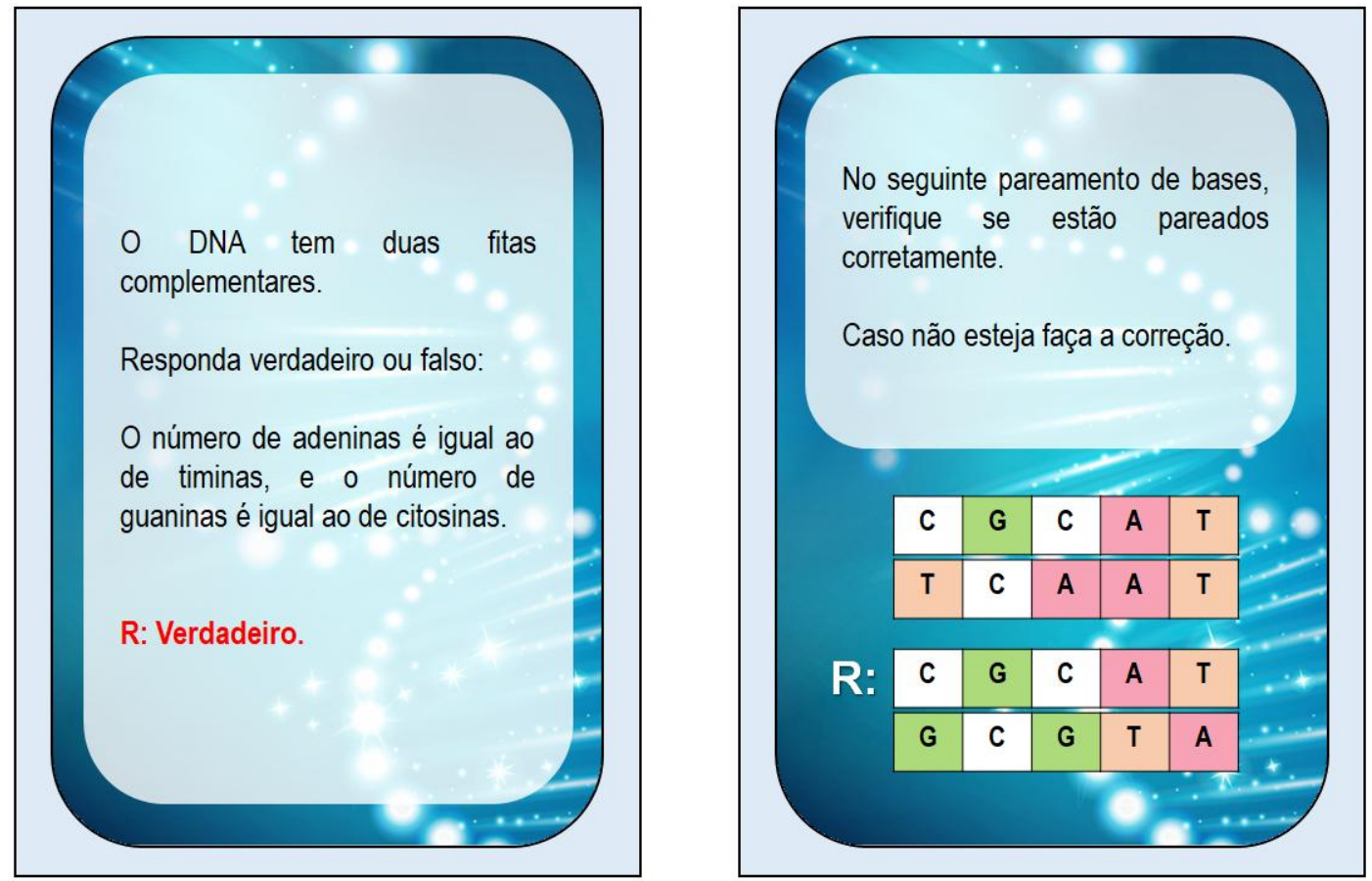

Fonte: Os autores (2020).

A intervenção se deu com uma turma de $3^{\circ}$ ano do Ensino Médio na Escola Estadual Centro de Ensino Renê Bayma, localizada no município de Codó (MA). Foi realizada uma breve revisão sobre o conteúdo hereditariedade e material genético na sala de aula e em seguida, a turma foi dividida em duas equipes, cada uma tinha um líder e uma lista com as regras do jogo impressa para leitura inicial.

O jogo possui duas placas, uma indicando o local de partida (entrada) e a outra, a chegada (saída). Um representante de cada equipe se posiciona ao lado do tabuleiro; conforme o transcorrer do jogo, são realizadas perguntas sobre o conteúdo para as equipes, cada equipe por vez; e, à medida que cada equipe responde corretamente, avança-se casas de acordo com as instruções recomendadas no tabuleiro, como por exemplo, avance duas casas. Quando a equipe responde de forma incorreta, sucedem-se as penalidades para as mesmas, segundo a lista de penalidades. Dessa forma, a equipe vencedora é a que primeiro chega à placa saída.

Para avaliar a efetividade do jogo, utilizou-se um questionário semiestruturado. Após a explicação e a aplicação do jogo, foi realizada uma avaliação com os 23 alunos participantes, por meio de um questionário com 10 questões (Anexo 04). Posteriormente, as respostas foram tabuladas e apresentadas em gráficos construídos com o programa Microsoft Excel 2010. 


\section{Resultados}

Quando foi realizada a revisão sobre o conteúdo de material genético e hereditariedade, observou-se que os alunos, apesar de já terem tido aula sobre o tema, não lembravam conceitos básicos, tais como a definição de gene. Isto evidencia que o ensino está, por vezes, vinculado a uma rápida memorização de termos sem qualquer reflexão. Além disso, os discentes apresentaram grande dificuldade em relacionar este conteúdo com seu cotidiano.

Durante a aplicação do jogo "Tabuleiro de Genes", houve grande interatividade entre os alunos de uma mesma equipe, na busca pelo maior número de acertos. Envolvidos pela competitividade, os alunos se interessaram em responder as questões do jogo e até solicitaram que fossem permitidas consultas em seus livros; porém como não condiz com as regras do jogo, não foi autorizado. Os alunos se divertiram e ao mesmo tempo adquiriram novas informações sobre o tema.

Foi perceptível que nas perguntas mais contextualizadas, os alunos tiveram dificuldades para interpretar e responder de forma correta. Além disso, também apresentaram dificuldades em reconhecer e relacionar as estruturas químicas presente na estrutura do DNA (por exemplo, a pentose) no tabuleiro genético.

Entre as principais respostas ao questionário de avaliação do jogo, a maioria dos alunos consideraram o jogo de fundamental importância para educação, pois além de dinamizar o ambiente escolar, eles aprenderam com ludicidade. Percebeu-se que mais da metade dos participantes do jogo consideraram o mesmo um instrumento pedagógico que auxilia o professor no ensino da sala de aula. Segundo Pereira et al. (2020) o jogo é uma estratégia de ensino que contribui na solidificação e motivação do aprendizado, sendo considerado instrumentos através do qual se articulam conhecimentos.

Quando os alunos foram questionados sobre a contribuição dessa atividade lúdica para o aprendizado, dos 23 participantes, $52 \%$ consideraram o método excelente e $48 \%$ consideraram o jogo de boa eficiência, estes valores são analisados como positivos, indicando eficácia do recurso proposto. O jogo "Tabuleiro de Genes" pode funcionar tanto para uma revisão conceitual, como para permitir visualização da estrutura espacial da molécula do DNA, facilitando a construção de representações mentais para os alunos. Segundo Martins (2017), o brincar pode ser visto como um recurso mediador no processo de ensino-aprendizagem, tornando-o mais acessível e enriquecedor da dinâmica das relações sociais na sala de aula.

Em relação à opinião dos alunos sobre a contribuição deste jogo para fixação de conceitos relacionados à Genética, 65\% dos alunos o consideraram como excelente para a 
fixação dos conteúdos, 31\% como um método bom e $4 \%$ classificaram o jogo como regular para esta finalidade. A compreensão de conceitos específicos da área de Genética é muito importante para a aprendizagem do aluno (SOUSA et al., 2017), que deve ser capaz de compreender os processos biológicos e suas estruturas, bem com estabelecer correlações e interrelações entre os diferentes processos celulares com os mecanismos genéticos (BISSOLI et al., 2018).

Nas respostas obtidas quanto à clareza das regras do jogo, foram constatadas $78 \%$ respostas positivas, enquanto que foram verificadas $13 \%$ negativas e $9 \%$ dos alunos se abstiveram em responder esse questionamento. Essa situação negativa pode ter sido ocasionada porque alguns discentes não estavam atentos durante a leitura e explicação das regras do jogo. Dos 23 discentes, 15 alunos afirmaram que não tiveram nenhum tipo de dificuldade em jogar e 8 alunos afirmaram ter apresentado dificuldades em jogar o recurso proposto.

Estudos têm mostrado as dificuldades no aprendizado da Genética, sendo isso atribuído ao fato do vocabulário genético ser amplo, complexo e com conceitos abstratos (RIVAS et al., 2011). Assim, os professores necessitam estar constantemente atualizados em relação aos conteúdos da área, buscando promover ações que auxiliem no aprendizado dos seus alunos, incluindo o uso de modelos didáticos que ajudem na construção do conhecimento (PEREIRA et al., 2020).

As sugestões acerca de melhorias ao jogo foram bem diversificadas (Figura 3). Cerca de $65 \%$ responderam que o jogo não necessitava de mudanças, atestando uma boa aceitação; $18 \%$ fugiram totalmente do assunto; $5 \%$ sugeriram que as perguntas fossem mais fáceis; enquanto que $4 \%$ apresentaram as seguintes três sugestões: maior quantidade de perguntas; diminuição do tamanho do tabuleiro e mudanças nas regras das penalidades.

O jogo "Tabuleiro de Genes" aborda os conteúdos de Genética trabalhados no Ensino Médio e pode ser utilizado para estimular a construção do conhecimento sólido dos alunos e não apenas uma simples memorização. Este jogo foi desenvolvido com o intuito de instigar a curiosidade de alunos pela busca do conhecimento, sendo que $100 \%$ das respostas confirmaram o estímulo que este recurso didático promoveu em relação à curiosidade dos alunos. 
Figura 3 - Sugestões dos alunos para melhoria do jogo e método de aplicação

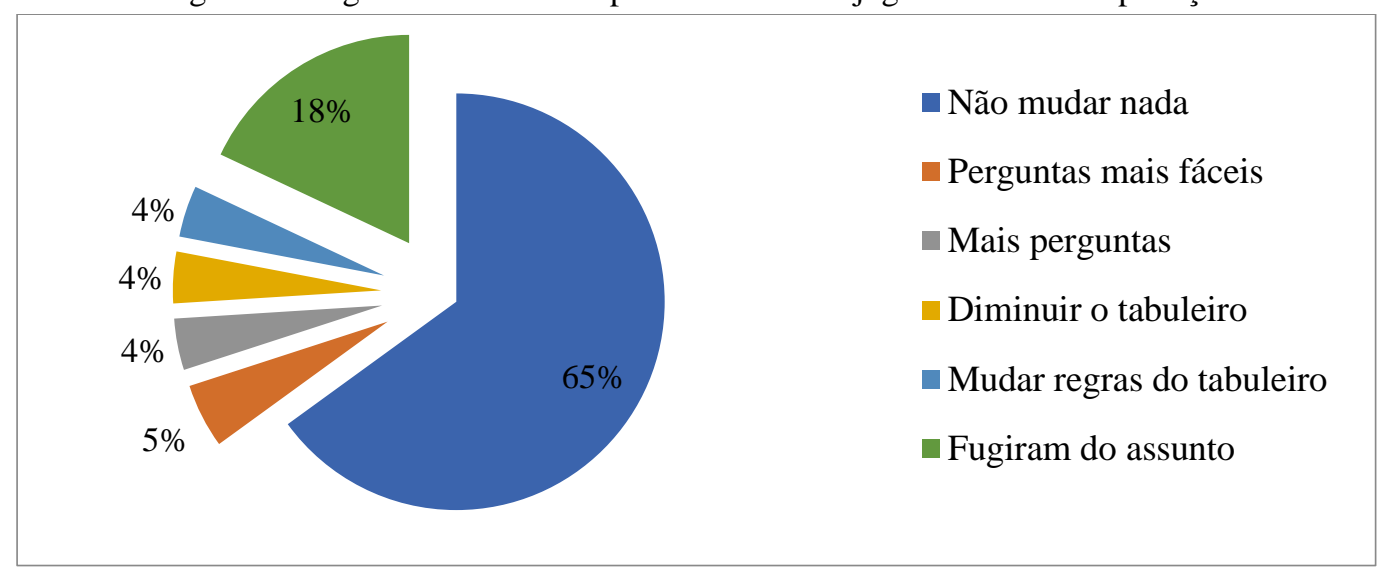

Fonte: Os autores (2020).

Quando se trabalha os conteúdos de Genética em sala de aula, os alunos logo se sentem intimidados, pois possuem muita dificuldade de compreensão em certos conceitos científicos e o conhecimento fragmentado não permite uma aprendizagem concreta (BELMIRO; BARROS, 2017). Por conseguinte, os alunos não conseguem relacionar conceitos básicos com as estruturas visuais, fato este identificado durante a aplicação do jogo. Apesar dos alunos estarem estudando exatamente o mesmo conteúdo abordado pelo jogo, estes não reconheciam certas definições e nem a estrutura do material genético, sendo esse o maior desafio na aplicação do jogo. Muitas perguntas ficaram sem respostas por parte das equipes o que comprometeu o maior dinamismo do jogo. Alguns alunos sugeriram como solução a redução do tamanho do tabuleiro e das regras, e durante a aplicação foi necessária uma adaptação do jogo com redução do tabuleiro de 15 para 12 casas.

Os resultados desta pesquisa indicaram que o conhecimento de Genética é muito superficial entre os jovens do Ensino Médio, sendo necessária uma abordagem mais intensificada da área, para uma aprendizagem significativa. Isso pode ser proporcionado por metodologias diferenciadas, como por exemplo, jogos didáticos. O jogo "Tabuleiro de Genes" proporcionou a interação dos alunos com os conteúdos relacionados à hereditariedade e material genético, além disso, pode ser uma alternativa viável às escolas que não dispõem de laboratórios didáticos.

\section{CONSIDERAÇÕES FINAIS}

O jogo "Tabuleiro de Genes" foi proposto visando à promoção de uma aprendizagem ativa no ensino de Genética, levando maior dinamismo e ludicidade ao conteúdo. A partir dos resultados da avaliação do jogo pelos estudantes, percebeu-se que os objetivos propostos foram 
alcançados, verificando-se que o recurso elaborado se apresenta como uma proposta metodológica eficiente de facilitação do processo de ensino-aprendizagem. Desta maneira, o “Tabuleiro de Genes" atua como importante ferramenta para compreensão de conteúdos de Genética, além de proporcionar novas habilidades e instigar a curiosidade entre os discentes. Ressalta-se ainda que este jogo pode ser utilizado por professores de Ciências e Biologia, como atividade complementar ao conteúdo de hereditariedade e material genético.

\section{REFERÊNCIAS}

ACRANI, Simone; BENEZE-JUNIOR, Roosevelt Antônio; NICULA, Beatriz Sales; PEIXOTO, Fernanda Ortiz; LOPES, Lane Astum; NOGUEIRA, Barbosa Rocha; FERNANDES, Raissa Dalila; SANTOS, Paula Pereira Baptista Ferreira. A utilização de jogos didáticos como estratégia de aprendizagem no ensino de biologia. Brazilian Journal of Development, v. 6, n. 2, p. 7930-7935, 2016. Disponível em:

http://www.brazilianjournals.com/index.php/BRJD/article/view/6986. Acesso em: 28 de maio de 2020

AMORIM, Myrna Cecília Martins dos Santos; OLIVEIRA, Eloiza Silva Gomes; SANTOS, Joel André Ferreira; QUADROS, João Roberto de Toledo. Aprendizagem e Jogos: diálogo com alunos do ensino médio-técnico. Educação \& Realidade, v. 41, n. 1, p. 91-115, 2016. Disponível em:

http://scielo.br/scielo.php?pid=S217562362016000100091\&script=sci_arttext. Acesso em: 29 de maio de 2020.

ARAÚJO, Alcione Maria de Sá Cavalcante. Lúdico: aprender de forma prazerosa. Caderno de Pesquisa, São Luís, v. 19, n. 3, 2012. Disponível em:

http://www.pppg.ufma.br/cadernosdepesquisa/uploads/files/Artigo\%205(41).pdf. Acesso em: 07 de maio de 2020.

BISSOLI, Anna Carolinne Ferreira; DOS SANTOS, Gustavo Antunes; CONDE, Sandro José. Produção de materiais didáticos para o ensino de genética na implementação da sala de aula invertida. Revista Ibero-Americana de Estudos em Educação, v. 13, n. 2, p. 468-478, 2018. Disponível em: https://periodicos.fclar.unesp.br/iberoamericana/article/view/11440. Acesso em: 27 de maio de 2020.

BELMIRO, Michel Stórquio; DE BARROS, Marcelo Diniz Monteiro. Ensino de genética no ensino médio: uma análise estatística das concepções prévias de estudantes pré-universitários. Revista Práxis, v. 9, n. 17, p. 95-102, 2017. Disponível em:

http://revistas.unifoa.edu.br/index.php/praxis/article/view/771. Acesso em: 27 de maio de 2020 .

BRÃO, Ariane Francielle Silva; PEREIRA, Ana Maria Teresa Benevides. Biotécnétika: possibilidade do jogo no ensino de genética. Revista Electrónica de Enseñanza e las Ciencias, v. 14, n. 1, p. 55-76, 2015. Disponível em:

http://reec.uvigo.es/volumenes/volumen14/REEC_14_1_4_ex826.pdf. Acesso em: 30 de maio de 2020 . 
CABRERA, Waldirléia Baragatti. A LUDICIDADE PARA O ENSINO MÉDIO NA DISCIPLINA DE BIOLOGIA: Contribuições ao processo de aprendizagem em conformidade com os pressupostos teóricos da Aprendizagem Significativa. 2007. 159f. Dissertação (Mestrado em Ensino de Ciências e Educação Matemática) - Universidade Estadual de Londrina, Londrina, 2007. Disponível em: https://www.sapili.org/livros/pt/cp025038.pdf Acesso em: 27 de abril de 2020.

CASTELÃO, Talita Borges; AMABIS, José Mariano. Motivação e ensino de genética: um enfoque atribucional. Resumos do $54^{\circ}$ Congresso Brasileiro de Genética, 16-19 de setembro, 2008.

FIALHO, Neusa Nogueira. OS JOGOS PEDAGÓGICOS COMO FERRAMENTAS DE ENSINO. Área Temática: Educação: Teorias, Metodologias e Práticas. 2008. Disponível em: https://educere.bruc.com.br/arquivo/pdf2008/293_114.pdf. Acesso em: 07 de maio de 2020.

GRIFFITHS, Anthony; WESSLER, Susan; CARROL, Sean; DOEBLEY, John. Introdução à Genética. 11 a ed. Rio de Janeiro: Guanabara Koogan, 2016.

KRASILCHIK, Myriam. Prática de ensino de biologia. Edusp, 2004.

KISHIMOTO, Tizuko Morchida. Jogo, brinquedo, brincadeira e a educação. Cortez editora, 2017.

MARTINS, Isabel Cristina Pinto; BRAGA, Petrônio Emanuel Timbó. Jogo didático como estratégia para o ensino de divisão celular. Essentia-Revista de Cultura, Ciência e Tecnologia da UVA, v. 16, n. 2, 2015. Disponível em: https://essentia.uvanet.br/index.php/ESSENTIA/article/view/27. Acesso em: 28 de maio de 2020.

MARTINS, Marina Costa; BARATELI, Luciana Oliveira; SILVA, Rodrigo Santos. Bioquímica da fotossíntese: O lúdico norteando a construção da aprendizagem. Revista CTS IFG Luziânia, v. 1, n. 2, 2017. Disponível em: http://cts.luziania.ifg.edu.br/index.php/CTS1/article/view/84. Acesso em: 07 de maio de 2020.

MASCARENHAS, Marcia de Jesus Oliveira; SILVA, Vanessa Campos; MARTINS, Paula Regina Pereira; FRAGA, Elmary da Costa; BARROS, Maria Claudene. Estratégias metodológicas para o ensino de genética em escola pública. Pesquisa em foco, v. 21, n. 2 , 2016. Disponível em:

http://ppg.revistas.uema.br/index.php/PESQUISA_EM_FOCO/article/view/1216. Acesso em: 28 de maio de 2020.

MELO, José Romário de; CARMO, Edinaldo Medeiros. Investigações sobre o ensino de genética e biologia molecular no ensino médio brasileiro: reflexões sobre as publicações científicas. Ciência \& Educação (Bauru), v. 15, n. 3, p. 592-611, 2009. Disponível em: https://www.scielo.br/scielo.php?script=sci_arttext\&pid=S151673132009000300009\&lng=pt \&tlng=pt. Acesso em: 07 de maio de 2020.

OLIVEIRA Rosa, Letícia; Mota, Fernanda Neves Normando; OLIVEIRA, Francisco Claudemir; BATISTA, Fani Tamires Sousa; DRFS, Yosie Dias Serrão; ROSA, Letícia de Oliveira. Jogo Bozó Genético: uma proposta didática como alternativa para o ensino da 
replicação do DNA no ensino médio. Revista de Ensino de Bioquímica, v. 14, n. 3, p. 57-67, 2016.

PEDROSO, Carla Vargas. Jogos didáticos no ensino de Biologia: uma proposta metodológica baseada em módulo didático. Eixo Temático: Didática: Teorias, Metodologias e Práticas, v.9, n.1, p. 3182-3190, 2009. Disponível em:

https://educere.bruc.com.br/arquivo/pdf2009/2944_1408.pdf. Acesso em: 27 de abril de 2020.

PEREIRA, Sara Souza; DA CUNHA, Joyciane Santiago; LIMA, Eldianne Moreira. Estratégias didático-pedagógicas para o ensino-aprendizagem de Genética. Investigações em Ensino de Ciências, v. 25, n. 1, p. 41-59, 2020. Disponível em:

https://www.if.ufrgs.br/cref/ojs/index.php/ienci/article/view/1462. Acesso em: 30 de maio de 2020.

REZENDE, Leandro Pereira; GOMES, Sâmea Cristina Santos. Uso de modelos didáticos no Ensino de Genética: estratégias metodológicas para o aprendizado. Revista de Educação, Ciências e Matemática, v. 8, n. 2, 2018. Disponível em: http://publicacoes.unigranrio.edu.br/index.php/recm/article/view/4447. Acesso em: 29 de maio de 2020.

SANTOS, Maurício Araújo; FREITAS, Wanderson Lopes dos Santos, LIMA, Sintiane Maria de Sá; LIMA, Michelle Mara de Oliveira. A genética no contexto de sala de aula: dificuldades e desafios em uma escola pública de Floriano-PI. Revista de Ensino de Ciências e

Matemática, v. 9, n. 1, p. 19-30, 2018. Disponível em:

http://revistapos.cruzeirodosul.edu.br/index.php/rencima/article/view/1300. Acesso: em $30 \mathrm{de}$ maio de 2020.

SILVA, Sergivaldo Leite. Os conteúdos da genética a partir do jogo didático trilha das ervilhas. 2019. Dissertação de Mestrado. Universidade Federal de Pernambuco.

SOARES, Vanessa Fernandes; CORREIA, Bruna Gomes; MELO, Quitéria Maria; SILVA, Chryslane Barbosa; SILVA, Kelly Barbosa; PEREIRA, Carla Karine Barbosa. A relevância dos jogos didáticos como ferramenta para auxílio do processo de ensino-aprendizagem de Biologia. Diversitas Journal, v. 1, n. 1, p. 64-67, 2016. Disponível em: https://periodicos.ifal.edu.br/diversitas_journal/article/view/295. Acesso em: 27 de maio de 2020.

SOUSA, Edjéssica Siqueira de; NUNES-JUNIOR, Francisco Holanda; CAVALCANTE, Cícero Antonio Maia; HOLANDA, Denise de Araújo Silva. A Genética Em Sala De Aula: Uma Análise Das Percepções E Metodologias Empregadas Por Professores Das Escolas Públicas Estaduais De Jaguaribe Ceará. Conexões-Ciência e Tecnologia, v. 10, n. 4, p. 16 24, 2017. Disponível em:

http://www.conexoes.ifce.edu.br/index.php/conexoes/article/view/1106. Acesso em: 20 de maio de 2020.

VENTURINI, Andressa Monteiro; SOUZA, Leandro Fonseca; DIAS, Naissa Maria Silvestre; MONTEIRO-VITORELLO, Claudia Barros; QUECINE, Maria Carolina. Aulas Práticas de Laboratório como Método de Ensino de Genética Molecular. Revista de Graduação USP, v. 3, n. 2, p. 81-85, 2018. Disponível em:

https://www.revistas.usp.br/gradmais/article/view/147909. Acesso em: 28 de maio de 2020. 
RIVAS, Priscila; PINHO, Jaqueline; BRENHA, Sérgio Luís. Experimentos em genética e bioquímica: motivação e aprendizado em alunos do ensino médio de uma escola pública do estado do maranhão. Ensino, Saude e Ambiente, v. 4, n. 1, 2011. Disponível em:

https://periodicos.uff.br/ensinosaudeambiente/article/view/21098. Acesso em: 30 de maio de 2020.

Recebido em: 31 de maio de 2020 .

Aprovado em: 29 de agosto de 2020. 


\section{Anexo 01: Perguntas do jogo de Tabuleiro de Genes.}

1. A área da Biologia que estuda a transmissão do material genético ao longo das gerações, a natureza química desse material e seu modo de ação é chamada de?

2. Qual a unidade básica da hereditariedade?

3. A estrutura do DNA é considerada, por muitos cientistas, como a descoberta mais importante do século XX. Qual é a estrutura do DNA?

4. As células contêm dois tipos de ácidos nucleicos. Quais são eles?

5. As unidades dos ácidos nucleicos são chamadas de?

6. Cada nucleotídeo é formado por três partes, quais são elas?

7. Na fita dupla de DNA, estabelece-se uma polaridade distinta nas extremidades de cada fita. Por isso, as fitas são chamadas de?

8. As bases nitrogenadas dos nucleotídeos são de dois tipos, quais são elas?

9. Quais são as bases purinas?

10. Quais são as bases pirimidinas?

11. O DNA tem duas fitas complementares. Responda verdadeiro ou falso: O número de adeninas é igual ao de timinas, e o número de guaninas é igual ao de citosinas.

12. Qual é o alelo que determina o mesmo fenótipo, tanto em homozigose como em heterozigose?

13. Qual é o alelo que se expressa apenas quando está em homozigose?

14. No seguinte pareamento de bases, verifique se estão pareados corretamente. Caso não esteja, faça a correção:

\section{CGCAT}

TCAAT

15. Antes do início da divisão celular, cada molécula do DNA do núcleo sofre duplicação, resultando em duas novas moléculas idênticas à que lhes deu origem. Como é chamado o processo de duplicação da fita de DNA?

16. Alguns fatores podem modificar alguns tipos de ligações existentes no DNA, favorecendo o pareamento errado entre as bases nitrogenadas durante a duplicação. Esse mecanismo é chamado de?

17. Qual sentido da replicação do DNA? 
18. Qual a função da enzima DNA helicase?

19. Qual a função da enzima topoisomerase?

20. Complete a sentença:

A desoxirribose é uma pentose, isto é, um carboidrato formado por cinco carbonos. Ao carbono 1' liga-se a e ao carbono no 5' liga-se o grupo 


\section{Anexo 02: Regras do jogo Tabuleiro de Genes}

1. A turma deverá ser dividida em duas equipes; e cada equipe escolhe um líder;

2. O aplicador do jogo deve ser o responsável pela turma;

3. O líder escolherá uma pessoa da equipe para percorrer o tabuleiro e responder as perguntas;

4. O líder da equipe pode consultar a resposta somente com integrantes da sua equipe;

5. Cada equipe terá no máximo 02 minutos para responder cada pergunta;

6. Cada equipe deverá ter em mãos caneta e papel em branco para auxiliar no jogo;

7. Para cada acerto da equipe, terá avanço de casas conforme instruções contidas no tabuleiro;

8. Para cada erro, haverá penalidades para equipe conforme lista de penalidades;

9. Caso a equipe não responda nada, o silêncio contará como erro;

10. A equipe que responder fora de sua vez receberá a penalidade de voltar uma casa no tabuleiro;

11. A equipe vencedora será aquela que conseguir primeiro completar o percurso do tabuleiro até o ponto de chegada.

Fica a critério do aplicador do jogo oferecer uma premiação à equipe vencedora. 


\section{Anexo 03: Penalidades do jogo}

1. Volte uma casa.

2. Volte duas casas.

3. Volte uma casa e o adversário responde.

4. Fique uma rodada sem jogar.

5. Volte três casas.

6. O mico é seu!

7. Volte uma casa.

8. Volte duas casas.

9. Volte uma casa.

10. Volte ao início do jogo.

11. Sua equipe perdeu 10 pontos.

12. Volte uma casa e responda uma pergunta; se errar volte mais uma casa.

Instruções:

Quando a equipe errar a primeira vez, aplicar a penalidade 1;

Quando a equipe errar a segunda vez, aplicar a penalidade 2; e assim por diante. 


\section{Anexo 04: Questionário de avaliação do jogo}

Em relação ao jogo, responda com um $\mathrm{X}$ os itens a seguir:

1. O jogo tem importância para a educação?

a) ( ) Ruim b) ( )Regular c) ( ) Boa ( ) Excelente

2. Este jogo serve para facilitar o aprendizado?

a) ( ) Ruim b) ( )Regular c) ( ) Bom d) ( ) Excelente

3. Você acha que este jogo serve para fixação de conceitos e como fonte de pesquisa?

a) ( ) Ruim b) ( )Regular c) ( ) Bom d) ( ) Excelente

4. Quanto às regras do jogo, foram claras?

a) ( ) $\operatorname{Sim}$ b) ( ) Não

5. Você teve dificuldade para jogar?

a) ( )Sim b) ( )Não

Se for sim, descreva essas dificuldades.

6. O jogo aborda os conteúdos que você estuda em Genética?

a) ( ) $\operatorname{Sim}$ b) ( )Não

7. Você acredita que este jogo pode ser usado como atividade complementar em sala de aula?

a) ( ) Sim b) ( )Não

8. Você indicaria o jogo para um professor aplicar para seus alunos?

a) ( )Sim b) ( )Não

9. O jogo despertou curiosidade para buscar mais informações sobre o assunto?

a) ( ) Sim b) ( )Não

10. Indique sucintamente o que poderia ser melhorado no jogo genético ou no método de aplicação em sala de aula. 